UDC 614.446: 1: 613: 11: 613.67

DOI: $10.21668 /$ health.risk/2019.3.18.eng

\title{
RISK ASSESSMENT FOR INCIDENCE WITH COMMUNITY-ACQUIRED PNEUMONIA IN ORGANIZED COMMUNITIES AMONG THIER MEMBERS ADAPTING TO TRAINING AND ACCLIMATIZATION
}

\author{
R.S. Rakhmanov ${ }^{1}$, N.N. Potekhina ${ }^{1}$, A.V. Tarasov ${ }^{2}$, I.N. Koldunov ${ }^{2}$ \\ ${ }^{1}$ Privolzhsky Research Medical University, 10/1 ploshchad' Minina i Pozharskogo, Nizhnii Novgorod, 603005, \\ Russian Federation \\ ${ }^{2}$ Immanuel Kant Baltic Federal University, 14 A. Nevskogo Str., Kaliningrad, 236016, Russian Federation
}

There is a pressing issue in prevention medicine related to improving approaches to detecting risk factors and reducing incidence with community-acquired pneumonia (CAP). Such approaches include analyzing health risks associated with adverse impacts exerted by environmental factors.

Our research goal was to assess incidence with CAP in initially healthy organized communities made up of cadets under influences exerted by a set of factors related to a body adapting to training at higher military educational establishments as well as to specific sea climate in Kaliningrad enclave.

We applied epidemiologic analysis to assess incidence with CAP in educational establishments with different training conditions. We determined peculiarities related to registering disease cases among local students and those who came from other Russian regions; we also comparatively analyzed annual incidence among first-year cadets.

Incidence among first- and second-year cadets was authentically higher than among senior ones. First-year students accounted for the greatest share in the overall incidence and it proved that adaptation to training was a truly significant factor. Incidence among cadets from other regions was higher and it proved that acclimatization to specific climatic and weather conditions was also a significant factor. Higher incidence among cadets who had poorer training conditions during their first and second training year confirmed that training conditions could also be considered a risk factor that caused CAP. Two peaks in annual morbidity among first years cadets were likely due to both a factor related to a new organized community formation and seasonal factors.

The fact that the disease is detected among cadets at each year makes it necessary to analyze incidence with CAP in order to detect probable "specific" risk factors and to provide differentiated prevention for each year.

Key words: educational establishments, cadets, community-acquired pneumonia, incidence, study cohorts, relative risk.

Community-acquired pneumonia (CAP) remains a significant social issue being a widely-spread disease among civilians and military personnel [1-3]. As per data provided by Rospotrebnadzor, in 2017 incidence with the disease amounted to 412.32 cases per 100 thousand people ${ }^{1}$. A number of virus pneumonia cases went down by 2 times against the previous year together with a registered decrease in incidence with flu; but there were practically no changes in a number of bacterial CAP cases and the incidence in 2017 was $4.3 \%$ higher than in 2016.

Children are the primary risk group as per CAP as the maximum incidence with the disease was registered among children aged 1-2 $(1,470.06$ per 100 thousand children of this age) [4], other risk groups include adults who suffer from pathologies in the upper respiratory tracts, overweight, pancreatic diabetes,

(C) Rakhmanov R.S., Potekhina N.N., Tarasov A.V., Koldunov I.N., 2019

Rofail' S. Rakhmanov - Doctor of Medical Sciences, Professor at the Hygiene Department (e-mail: raf53@mail.ru; tel.: +7 (910) 792-89-82; ORCID: https://orcid.org/0000-0003-1531-5518).

Natal'ya N. Potekhina - Doctor of Medical Sciences, Professor at the Hygiene Department (e-mail: nn-potechina@yandex.ru; ORCID: ORCID: https://orcid.org/0000-0001-6519-5513).

Andrei V. Tarasov - Candidate of Medical Sciences, Associate Professor at the Fundamental Medicine Department (e-mail: drup1@yandex.ru; tel.: +7 (911) 468-15-31; ORCID: https://orcid.org/0000-0001-5749-1216).

Ivan N. Koldunov - Candidate of Medical Sciences, Senior lecturer at the Therapy Department (e-mail: drup1@yandex.ru; tel.: +7 (952) 054-76-43; ORCID: https://orcid.org/0000-0001-7845-0800).

${ }^{1}$ On sanitary-epidemiologic welfare of the population in the Russian Federation in 2017: State Report. Moscow, The Federal Service for Surveillance over Consumer Rights Protection and Human Well-being Publ., 2018, 268 p. (in Russian). 
chronic lung and liver diseases, as well as reinforcements who start their military service [2, 5]. A factor related to adaptation and acclimatization was significant among students and cadets who attended higher educational establishments [6-12] and had to adapt themselves to specific occupational training [11]. A period during which there was a risk of an increase in incidence with CAP was determined for foreign students of a military HEE [6]; researchers also revealed a role played by seasonal acclimatization of the respiratory system (especially in September and October) in greater loads on the system accompanied with an increase in respiratory organs diseases [12]. Nevertheless, there has been no research or differentiated analysis on incidence with CAP among cadets in a specific climatic region only during a period of adaptation to training conditions as well as acclimatization to specific weather conditions.

To prevent CAP, there is immunization against pneumococcal infections both among children within the national prevention vaccination schedule (Prevenar-13 13-valent conjugated vaccine) and adults from risk groups (23-valent polysaccharide pneumococcal vaccine) that is quire efficient $[13,14]$. A set of preventive and anti-epidemic activities allowed to decrease incidence with CAP among draft military personnel from $69.6 \%$ in 2010 to $27.2 \%$ in 2017 , that is, by 2.6 times. However, this incidence still remains high in comparison to current incidence among contracted military personnel $(5.3 \%$ ) and population $(8.8 \%)$ [15].

Therefore, there is still a vital issue in practical medicine regarding improved approaches to risk factors determination and a decrease in CAP incidence. Several authors state it is necessary to create and implement programs aimed at preventing respiratory organs diseases, and at modeling criteria for determining risk groups as per bronchopulmonary pathology $[6,12]$. Such mechanisms include health risk analysis methodology which can be applied to analyze risks caused by negative impacts exerted by adverse environmental factors [16].
Our research goal was to assess incidence with CAP among initially healthy cadets from organized teams under influences exerted by a set of factors related to a body adapting to training conditions at a military HEE and acclimatization to sea climate in $\mathrm{Ka}-$ liningrad enclave.

\section{Research tasks:}

1. To apply epidemiologic analysis in order to assess incidence with communityacquire pneumonia at two military higher educational establishments with different training conditions;

2. To assess influence exerted by acclimatization on incidence with CAP among cadets from military HEE, both coming from Kaliningrad region and those who came to Kaliningrad enclave from other Russian regions;

3. To perform comparative analysis of annual incidence with CAP among first-years students at both establishments;

4. To determine relative risk of incidence with CAP in teams with synergic environmental factors that differed in their intensity.

Data and methods. We performed cohort studies at two military higher educational establishments in Kaliningrad region.

We accomplished a retrospective comparative analysis of incidence with CAP at two military HEE over 5 years (September 2012 - September 2017) under the same influences exerted by Baltic Sea climate. Cadets didn't have any preventive vaccination against CAP before they arrived at a HEE and during their training. Cadet teams had some differences in their parameters such as different occupational assignments, hygienic placement conditions, meals, and a ratio of cadets from Kaliningrad region and those who came from other regions. At the first HEE, shares of local students and those who came from other regions amounted to $57.7 \%$ and $42.3 \%$ : at the second one, $13.2 \%$ and $86.8 \%$ respectively.

Cadets from the first HEE lived in standard modern buildings and air per 1 person in first-year students bedrooms amounted to $16,3 \mathrm{~m}^{3}$, and in the second HEE, to $9,9 \mathrm{~m}^{3}$. Cadets from the 2nd HEE lived in premises 
built in 20-30ties of the 20th century (nonstandard buildings with basements). 20 cadets lived in each room, and air per 1 person in bedrooms for the first and second year students amounted to $9.9 \mathrm{~m}^{3}$; temperature inside might drop to $16-18^{0} \mathrm{C}$ in late September or early October, and there was increased humidity inside.

Meals were delivered by an outsource company (a choice of 3-4 dishes per each meal) or they were provided by HEE itself according to a ration schedule (one dish per a meal).

We assessed incidence (per 1 thousand people, \%o) as per training years (1-5) and determined peculiarities related to diseases registration from the 1 st to 5 th year. Applying the same approach, we assessed incidence among local cadets and those who came from other Russian regions. These data were considered to show dependence of the disease on natural resistance of a body and acclimatization. We examined annual and long-term dynamics of incidence.

We determined relative risks (OR) for incidence with CAP in cadet teams with different influences exerted by synergic environmental factors with a PC program.

The results were statistically processed with AtteStat software package. Validity of discrepancies between incidence levels was determined with Student's t-test.

Results and discussion. The climate in Kaliningrad enclave has some peculiarities that make it rather distinct from other regions in the Russian Federation:

1. Radiation balance is negative during four months (from November to February): substantial cloud cover reduces direct sun radiation income by $50-60 \%$;

2. The territory is exposed to cyclonic circulation for 173 days a year and it makes the sky cloudy and causes moderate and strong winds;

3. Relative air humidity is $81-82 \%$, but in autumn and winter it goes up to $85-89 \%$. High humidity and heavy cloudiness exert significant influence on changes in light conditions (there are only 30-33 sunny days a year);
4. Annually there are 178-183 days with precipitation in the region. There are also frequent fogs (in November-December and in March, they last for 30-40 hours) [8,9];

Diseases from the "Diseases of the respiratory system" category took the first rank place in the incidence structure at both HEE, accounting for $52.1 \%$ and $70.9 \%$ accordingly.

Over the analyzed period, incidence at the first HEE was 2.5 times lower than in the second one, $20.7 \pm 3,1 \%$ against $51.2 \pm 3,8 \%$, $\mathrm{p}=0.000$. We analyzed incidence as per training years and found out that authentic discrepancies occurred only during the 1st year as the figure was 2.52 times higher at the second HEE (Table 1).

Table 1

Incidence with CAP in two educational establishments as per training years, \%o

\begin{tabular}{|c|c|c|c|}
\hline \multirow{2}{*}{$\begin{array}{c}\text { Training } \\
\text { year }\end{array}$} & \multicolumn{2}{|c|}{ Compared groups } & \multirow{2}{*}{$\begin{array}{c}\mathrm{p}=\text { HEE } 1 / \\
\text { HEE } 2\end{array}$} \\
\hline & HEE 1 & HEE 2 & \\
\hline 1 & $46.9 \pm 8.2$ & $118.2 \pm 9.6$ & 0.000 \\
\hline 2 & $\begin{array}{l}22.8 \pm 6.2 \\
p=0.019^{*}\end{array}$ & $\begin{array}{l}34.3 \pm 6.1 \\
p=0.000 *\end{array}$ & 0.188 \\
\hline 3 & $\begin{array}{c}6.3 \pm 3.6 \\
\mathrm{p}=0.022^{* *}\end{array}$ & $\begin{array}{c}7.5 \pm 3.3 \\
p=0.000 * *\end{array}$ & 0.808 \\
\hline 4 & $3.3 \pm 3.3$ & $9.9 \pm 4.9$ & 0.274 \\
\hline 5 & $6.5 \pm 6.5$ & $4.0 \pm 4$ & 0.742 \\
\hline
\end{tabular}

Note: *p1-2;**p2-3.

Trends in incidence registration from the 1 st to 5 th year were quite similar at these two HEE as the absolute decrease amounted to $10.1 \%$ in the first one, and $28.5 \%$ in the second one, decrease rate being equal to $18.6 \%$ and $44.2 \%$ respectively. Incidence with CAP authentically decreased at the second training year, by 2.1 times at the first HEE $(p=0.019)$, and by 3.4 times, at the second one $(\mathrm{p}=0.000)$. However, it was still higher than at the 3rd training year, by 3.6 and 4.6 times respectively. And any discrepancies between incidence at the examined HEE disappeared only at the 3rd-5-th year.

Overall, incidence was higher among cadets who came from other regions than among local ones, by 2.0 times at the first HEE, and by 1.52 times, at the second one (Table 2 ). In 
turn, incidence among cadets was authentically higher at the second HEE than at the first one, by 2.6 and 3.0 times respectively.

Table 2

Incidence with CAP at two HEE among local cadets and those who came from other RF regions, \%o

\begin{tabular}{|c|c|c|c|}
\hline \multirow{2}{*}{ HEE } & \multicolumn{2}{|c|}{ Cadets } & \multirow{2}{*}{$\mathrm{p}=$ local/other } \\
\cline { 2 - 3 } & Local & $\begin{array}{c}\text { From other } \\
\text { regions }\end{array}$ & \\
\hline 1 & $14.2 \pm 3.9$ & $28.8 \pm 4.7$ & 0.017 \\
\hline 2 & $\begin{array}{c}43.0 \pm 10.2 \\
\mathrm{p}=0.008\end{array}$ & $\begin{array}{c}65.4 \pm 4.5 . \\
\mathrm{p}=0.000\end{array}$ & 0.046 \\
\hline
\end{tabular}

We analyzed incidence as per training years in both cadets cohorts and revealed the same dependence (Tables 3 and 4). Authentic discrepancies between incidence levels among local cadets and cadets from other regions were registered only at the 1st training year. Incidence was 3.0 times higher among cadets from other regions at the first HEE, and 1.74 times higher, at the second one. However, at the first HEE there were no discrepancies in incidence among local cadets between the 1st and the 2nd training year, but as for cadets from other regions, incidence at the 2 nd training year was 2.2 times lower than at the $1 \mathrm{st}$ one and there were no discrepancies in incidence levels at the 2nd and 3rd year.

As for the 2nd HEE, incidence with CAP was lower at the 2nd training year that at the 1st one, both among local cadets and those who came from other regions, by 1.7 times and 4.0 times respectively. There were no authentic discrepancies in it at the 3rd training year among local cadets, but incidence among cadets from other regions was 3.2 times higher. There were no discrepancies in incidence among local cadets and cadets form other regions at the 3rd - 5th training years.

We analyzed incidence with CAP among first-year cadets at the first HEE in its long-term dynamics and reveled a descending trend (an absolute annual decrease was equal to $8.5 \%$ o). Rises in incidence against the basic trend were detected in 2012-2013 and 2014-2015 training years. We detected an
Table 3

Incidence with CAP in the first HEE as per training years, \%o

\begin{tabular}{|c|c|c|c|}
\hline \multirow{2}{*}{$\begin{array}{c}\text { Incidence as } \\
\text { per training } \\
\text { years }\end{array}$} & \multicolumn{2}{|c|}{ Cadets } & $\mathrm{p}=$ local/ \\
\cline { 2 - 3 } other
\end{tabular}

Note: *p1-2; 2-3 etc.

Table 4

Incidence with CAP in the second HEE as per training years, $\%$ o

\begin{tabular}{|c|c|c|c|}
\hline \multirow{2}{*}{$\begin{array}{c}\text { Incidence as } \\
\text { per training } \\
\text { years }\end{array}$} & \multicolumn{2}{|c|}{ Cadets } & \multirow{2}{*}{$\begin{array}{c}\mathrm{p}=\text { local } / \\
\text { other }\end{array}$} \\
\hline & Local & $\begin{array}{c}\text { From other } \\
\text { regions }\end{array}$ & \\
\hline 1 & $75.2 \pm 22.9$ & $131.0 \pm 10.7$ & 0.027 \\
\hline 2 & $\begin{array}{c}44.2 \pm 19.3 \\
\text { p1-2 }=0.302^{*}\end{array}$ & $\begin{array}{c}32.9 \pm 0.6 \\
\mathrm{p} 1-2=0.000\end{array}$ & 0.578 \\
\hline 3 & $\begin{array}{c}11.8 \pm 11.7 \\
\text { p2-3 }=0.152\end{array}$ & $\begin{array}{c}10.3 \pm 4.2 \\
\mathrm{p} 2-3=0.003\end{array}$ & 0.909 \\
\hline 4 & $11.9 \pm 14.1$ & $9.9 \pm 4.9$ & 0.894 \\
\hline 5 & $16.9 \pm 16.8$ & $7.4 \pm 4.3$ & 0.582 \\
\hline
\end{tabular}

Note: *p1-2; p2-3 etc.

ascending trend in incidence at the second HEE with its absolute annual growth being equal to 28\% and rises in incidence in 2013-2014 and 2015-2016. In those years up to $80 \%$ disease cases were detected among first- and secondyear cadets, with first-year cadets accounting for $60 \%$ of them.

CAP cases were detected at both HEE year-round, however, the upper limit of allyear incidence (ULAYI) was 1.8 times higher at the second HEE than at the first one and amounted to $4.4 \%$ against $2.4 \%$ at the first HEE (Figure). Monthly incidence dynamics was the same and tended to have two seasonal rises, from August to December, and from February to March, however, their intensity was different as the peak incidence was 3.8 times 
higher at the second HEE during its epidemic rise and reached $22.2 \%$, against $5.9 \%$ at the first HEE and it means there were active risk factors at the second HEE.

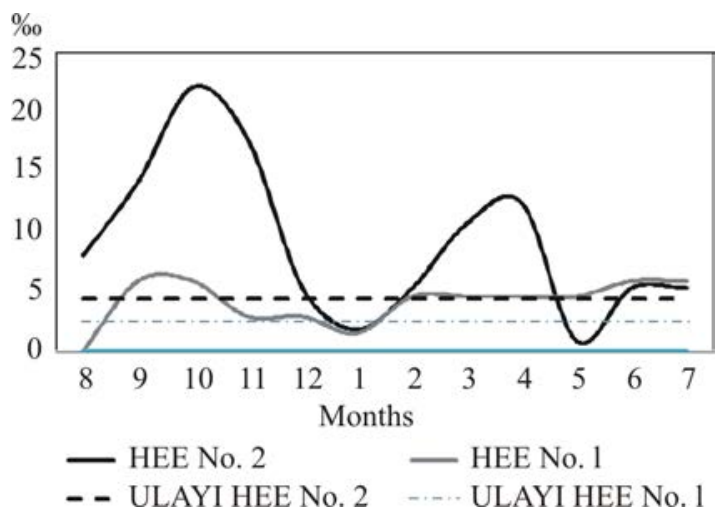

Figure. Annual incidence with CAP among first-year cadets, $\%$

Relative risk of incidence with CAP was higher at the second HEE than at the first one and amounted to 2.436 units; it was due to difference in influences exerted by synergic environmental factors. Relative risk of incidence with CAP among first- and second-year cadets was also higher, $\mathrm{OR}=2.411$ and $\mathrm{OR}=1.855$.

A set of these factors exerted more apparent impacts on incidence among cadets at the second HEE, both local ones and those who came from other Russian regions, $\mathrm{OR}=3.036$ and $\mathrm{OR}=1.932$.

Acclimatization-related processes in a body made their own contribution into incidence as it was proven by relative risk values at each HEE, its value being equal to 2.462 at the first HEE, and to 1.569, at the second one.

All the research results were obtained via analyzing incidence with CAP on a specific territory with its weather and climatic peculiarities. Physical environmental factors produced negative effects on health during different seasons [17-19]. Two rises in annual incidence among first-year cadets were probably caused by both factors related to a new team formation and seasonal factors. In its turn, incidence among cadets who came from other regions proved that adaptation mechanisms were a significant risk factor in case of such pathology.
Our research was based on the following propositions:

analysis performed on cohorts that include initially healthy people allows to reveal factors that play a significant role in epidemiologic process development and determine various "approaches" to preventing the disease;

total incidence and incidence with respiratory organs diseases to a certain extent reflects immunity level and characterizes how adapted young men are to training conditions [10];

health is an indicator related to influences exerted by synergic adverse environmental factors and training-related factors and it should be taken into account when implementing medical and preventive activities [11].

Analysis of incidence with CAP among initially healthy cadets who attended two HEE allowed to reveal the same peculiarities.

1. Average incidence with CAP was authentically higher among first- and secondyear cadets than among senior ones. First-year students accounted for the major share of incidence with CAP and it proved that a factor related to adaptation to training conditions was truly significant.

2. Incidence at each HEE had a correlation with a share of cadets who were not accustomed to local weather and climatic conditions; it proved that acclimatization factor was significant as adverse impacts exerted by Baltic Sea climate on health of cadets who came from other Russian regions became apparent via excess incidence. It allowed us to conclude that these weather and climatic conditions were clinically irritating for this category of people.

3. Training conditions also had their effects on incidence with CAP as it was proven by higher incidence among first- and secondyear students at the second HEE and it meant they were risk factors that could probably cause CAP.

4. Relative risks calculated among cadets from two HEE as per different training years and different cohorts (local cadets and those from other regions) proved that synergic environmental conditions exerted its influence on incidence with CAP. 
The obtained data allowed to conclude that first-year cadets ran the highest risks of CAP. Training conditions at a military HEE cause increased incidence both during the first and the second training year. Cadets who come to Kaliningrad enclave from other regions also run elevated CAP risks.

Disease registration that takes place at each training year determines the necessity to perform a retrospective analysis of incidence with CAP in order to reveal "specific" risk factors and probably differentiated activities aimed at CAP preventing among cadets at each training year.

Funding. The research was not granted any sponsor support.

Conflict of interests. The authors state there is no any conflict of interests.

\section{References}

1. Chuchalin A.G. Pneumonia as an actual medical problem of the 21th century. Russian Pulmonology. Terapevticheskii arkhiv, 2016, no. 4, pp. 4-1. DOI: 10.17116/terarkh20168834-12 (in Russian).

2. Ensuring sanitary and epidemiological welfare in the armed forces of the Russian Federation in 2017. Zdorov'e naseleniya i sreda obitaniya, 2018, vol. 298, no. 1, pp. 16-19 (in Russian).

3. Bilichenko T.N., Bystritskaya E.V., Chuchalin A.G., Belevskiy A.S., Batyn S.Z. Mortality of respiratory disease in 2014-2015 and ways of its improvement. Pul'monologiya, 2016, vol. 26, no. 4, pp. 389-397 (in Russian). DOI: 10.18093/0869-0189-2016-26-4-389-397

4. Mavzyutova G.A., Mukhamadieva L.R., Fazlyeva R.M., Mirsaeva G.Kh., Tyurina E.B. Rational immunotherapy in the combination treatment of community-acquired pneumonia. Meditsinskii sovet, 2015, no. 16, pp. 68-73 (in Russian).

5. Bilichenko T.N., Chuchalin A.G. Morbidity and mortality of the Russian population from acute respiratory viral infections, pneumonia and vaccination. Terapevticheskii arkhiv, 2018, no. 1, pp. 22-26 (in Russian). DOI: 10-17116/terarkh201890122-26

6. Balashov V.N., Udovichenko O.A., Evdokimov V.G. Climate impact on health and respiratory pathology development in foreign people studying at the Russian military academy. Byulleten' fiziologii i patologii dykhaniya, 2014, no. 51, pp. 69-74 (in Russian).

7. Rakhmanov R.S., Tarasov A.V. Otsenka riska zdorov'yu pri adaptatsii i akklimatizatsii v usloviyakh regiona Baltiiskogo morya [Health risk assessment for a period of adaptation and acclimatization to conditions existing in the Baltic Sea region]. Sovremennye metodologicheskie problemy izucheniya, otsenki i reglamentirovaniya faktorov okruzhayushchei sredy, vliyayushchikh na zdorov'e cheloveka: Materialy Mezhdunarodnogo foruma. Moscow, 2016, vol. 2, pp. 159-161 (in Russian).

8. Tarasov A.V. Otsenka riska dlya zdorov'ya u lits organizovannogo kollektiva $v$ usloviyakh adaptatsii [Health risk assessment for people from an organized community for a period of adaptation]. Sanitarnyi vrach, 2013, no. 9, pp. 42-44 (in Russian).

9. Tarasov A.V., Koldunov I.N., Rakhmanov R.S. On the issue of optimization of adaptation process to new environment taking into consideration climate and weather conditions. Gigiena $i$ sanitariya, 2014, no. 1, pp. 58-60 (in Russian).

10. Kolomiets O.I., Petrushkina N.P., Makunina O.A. Morbidity and vegetative status of the firstyear students as indicators of adaptation strategies to higher education. Uchenye zapiski, 2015, vol. 119, no. 1, pp. 97-104 (in Russian).

11. Kiku P.F., Mel'nikova I.P., Sabirova K.M. Hygienical assessment of factors of educational and production environment of cadets of higher marine educational institution. Ekologiya cheloveka, 2018, no. 3, pp. 21-26 (in Russian).

12. Grigor'eva E.A., Kir'yantseva L.P. Weather as a risk factor in respiratory morbidity and preventive measures among students. Byulleten' fiziologii i patologii dykhaniya, 2014, pp. 62-68 (in Russian).

13. Kozlova I.I., Sisin E.I., Ostapenko N.A., Ezhova O.A., Kashapov N.G. Analysis of the effectiveness of the implementation of the pilot project of vaccination against pneumococcal infection in risk groups in the municipalities leading on indicators of mortality from community-acquired pneumonia. Zdorov'e naseleniya i sreda obitaniya, 2018, vol. 298, no. 1, pp. 24-26 (in Russian).

14. Gruzdeva O.A., Bilichenko T.N., Vorontsova V.A, Uvarova A.A. Morbidity of influenza, other acute respiratory viral infections and pneumonia in population of the Central district of Moscow, 
2012-2016, and vaccine prevention. Pul'monologiya, 2017, vol. 27, no. 6, pp. 732-739 (in Russian). DOI: 10.18093/0869-0189-2017-27-6-732-739

15. Zhogolev S.D., Kulikov P.V., Zhogolev K.D., Aminev R.M., Zhogolev D.K., Zhurkin M.A., Kharitonov M.A., Gumilevskii B.Yu. Epidemiologicheskaya kharakteristika i sovershenstvovanie profilaktiki vnebol'nichnykh pnevmonii v voinskikh kollektivakh [Epidemiologic characteristics and improvement of prophylaxis activities aimed at preventing community-acquired pneumonia in military teams]. VI Luzhskie nauchnye chteniya. Sovremennoe nauchnoe znanie: teoriya i praktika: Materialy mezhdunarodnoi nauchnoi konferentsi. St. Petersburg, Leningradskii gosudarstvennyi universitet im. A.S. Pushkina Publ., 2018, pp. 145-148 (in Russian).

16. Onishchenko G.G. Health risk assessment and management as an effective tool to solve issues to ensure the health and epidemiological well-being of the Russian Federation population. Health Risk Analysis, 2013, pp. 4-14. DOI: 10.21668/health.risk/2013.1.01.eng

17. Rakhmanov R.S., Potekhina N.N., Grishin I.A., Piskarev Yu.G., Basalyga V.N., Sgibnev D.V., Mikhanoshina N.V., Tarasov A.V. Epidemiological features of communityacquired pneumonia under extreme natural-climatic conditions. Zdorov'e naseleniya i sreda obitaniya, 2017, vol. 289, no. 4, pp. 53-56 (in Russian).

18. Rakhmanov R.S., Potekhina N.N., Grishin I. A., Sgibnev D.V, Tarasov A.V. On prevention of community-acquired pneumonia among adults in organized groups. Zdorov'e naseleniya i sreda obitaniya, 2017, vol. 297, no. 12, pp. 29-33 (in Russian).

19. Mikhanoshina N.V. Zabolevaemost' lits organizovannogo kollektiva $\mathrm{v}$ razlichnykh pogodnoklimaticheskikh usloviyakh Dal'nego Vostoka [Incidence among people from organized communities under various natural and climatic conditions in the Far East]. Sanitarnyi vrach, 2013, no. 9, pp. 61-63 (in Russian).

20. Zhogolev S.D., Ogarkov P.I., Zhogolev K.D., Ivannikov Yu.G., Shipitsyn K.S., Kolesnikov V.V., Zharkov D.A. Epidemiology and prophylaxis of community-acquired pneumonia in servicemen. Voennomeditsinskii zhurnal, 2013, vol. 334, no. 11, pp. 55-60 (in Russian).

Rakhmanov R.S., Potekhina N.N., Tarasov A.V., Koldunov I.N. Risk assessment for incidence with community-acquired pneumonia in organized communities among thier members adapting to training and acclimatization. Health Risk Analysis, 2019, no. 3, pp. 154-160. DOI: 10.21668/health.risk/2019.3.18.eng

Received: 02.03.2019

Accepted: 26.07.2019

Published: 30.09.2019 